Farit Khoiruddin, Tri Kurniastuti \& Palupi Puspitorini, 2018. Pemberian Abu Sekam dan Pupuk NPK Terhadap Pertumbuhan dan Hasil Tanaman Tomat (Lycopersicum esculentum. Mill) Varietas Servo. Journal Viabel Pertanian. (2018), 12(2) 40 - 49

\title{
PEMBERIAN ABU SEKAM DAN PUPUK NPK TERHADAP PERTUMBUHAN DAN HASIL TANAMAN TOMAT (Lycopersicum esculentum Mill.) VARIETAS SERVO
}

\author{
Farit Khoiruddin $^{1}$, Tri Kurniastuti ${ }^{2}$ dan Palupi Puspitorini ${ }^{2}$
}

1. Mahasiswa Program Studi Agroteknologi Fakultas Pertanian, Universitas Islam Balitar, Blitar 2. Dosen Program Studi Agroteknologi Fakultas Pertanian, Universitas Islam Balitar, Blitar

\section{ABSTRACT}

This study aims 1) This study aims to reveal the differences between the growth and yield of tomato plants. 2) Knowing the difference between NPK fertilizer and the growth and yield of tomato plants. 3) Knowing the interaction between husk ash and NPK fertilizer on the growth and yield of tomato plants. This research was conducted using factorial randomized block design (RCBD) with 2 factors, the first factor was husk ash (A) consisting of 3 levels, namely $50 \mathrm{~g}(A 1), 60 \mathrm{~g}(A 2), 70 \mathrm{~g}(\mathrm{A3})$. The second factor is NPK fertilizer (P) consisting of 3 levels: $2.50 \mathrm{~g}(\mathrm{P1}), 3.75 \mathrm{~g}$ (P2), $5 \mathrm{~g}$ (P3). Variables that mention include plant height, number of leaves, time of flowering plants, number of fruit plants and fruit weight. Analysis date using analysis of variance (ANOVA) level of 5\% and further testing with Duncan's Multiple Distance Test (DMRT). The results showed that: There was no real interaction between rice husk ash fertilizer and NPK fertilizer on the growth and yield of tomato plants. Treatment of $70 \mathrm{~g}$ husk ash dose (A3) significantly affected plant height at the age of 14, 21, 28, and 42 HST. The treatment of NPK fertilizer $(P)$ is of real value for plant height, number of leaves and fruit weight. The best plant height was $52.18 \mathrm{~cm}$ and 84.06 at the age of 28 and 42 days after planting, the best number of leaves in puppol was $3.75 \mathrm{~g}(\mathrm{P} 2)$. But in people who are sweet, the yield is not significant.

\section{Keywords : Ash Husk, NPK Fertilizer, Tomato Plant. \\ PENDAHULUAN}

Tomat (Lycoprsicum esculentum Mill.) merupakan komoditas sayuran yang peminatnya terhadap komoditas ini dari tahun ketahun terus meningkat. Oleh sebab itu peluang bisnis buah tomat masih terbuka lebar karena pasokan dari tahun ke tahun belum mencukupi, baik untuk memenuhi konsumen domestic maupun manca Negara. Menurut Departemen Pertanian (2004), hasil buah tomat tahun 2000 sebesar 593.392 ton dan tahun 2003 sebesar 657.459 ton. Selanjutnya Neraca perdagangan BPS (2001), nilai defisit ekspor di Indonesia adalah 83.747 US \$ tahun 1997 meningkat sebesar 307.473 US \$. Tahun 2001.

Upaya memanfaatkan peluang pasar tersebut maka produksi komoditas tomat di Indonesia perlu ditingkatkan, salah satu upaya adalah intensifikasi pertanian yaitu usaha meningkatkan potensi tanaman agar mampu berproduksi tinggi. Sujiprihati et al. (2001) dalam Wiryanta (2000) menyatakan luas areal tomat di Indonesia dari tahun 1981-1992 
Farit Khoiruddin, Tri Kurniastuti \& Palupi Puspitorini, 2018. Pemberian Abu Sekam dan Pupuk NPK Terhadap Pertumbuhan dan Hasil Tanaman Tomat (Lycopersicum esculentum. Mill) Varietas Servo. Journal Viabel Pertanian. (2018), 12(2) 40 - 49

telah meningkat dua kali lipat, selanjutnya Surawinata (2003) menambahkan luas area tomat tahun 2003 mencapai 62.302 ha. Intensifikasi dilakukan dengan harapan mampu meningkatkan produksi sesuai atau lebih dari potensi hasil tanaman.

Pemupukan sebagai salah satu bagian usaha intensifikasi pertanian merupakan usaha yang bertujuan manambah persediaan unsure hara dibutuhkan tanaman untuk meningkatkan produksi dan matu hasil tanaman. Seiring perkembangan pertanian saat ini untuk menuju pertanian berkelanjutan maka salah satu alternatif adalah penggunaan bahan organik dan anorganik sebagai sumber hara untuk meningkatkan pertumbuhan dan hasiltanaman tomat.

Akhir-akhir ini penggunaan limbah pertanian ataupun perkotaan mulai banyak dipilih dan diperhatikan sebagai sumber bahan organic, karena selain menghasilkan biomasa banyak juga mudah diperoleh. Limbah pertanian abu sekam merupakan bahan berserat mengandung selulosa, lignin, hemiselulosa dan jika dibakar menghasilkan abu dengan silica cukup tinggi $87 \%$ - $97 \%$,serta mengandung hara $\mathrm{N} 1 \%$ dan $\mathrm{K} 2 \%$. Pemberian abu sekam pada tomat berpengaruh nyata terhadap laju pertumbuhan tinggi tanaman serta menekan serangan hama penyakit. Peran kalium dalam abu sekam adalah memperkuat tubuh tanaman agar daun dan bunga tidak gugur, pengaturan pernafasan, transpirasi, kerja enzim dan memelihara potensial osmosis serta pengambilan air merangsang pembentukan bulu-bulu akar, mengeraskan batang tanaman sekaligus merangsang pembentukan biji. Sedangkan peran silicon sebagai pemacu pertumbuhan beberapa tanaman gramineae terutama pada konsentrasi atau dosis optimal (martanto,2001).

Pupuk NPK merupakan pupuk majemuk yang mengandung unsur hara utama lebih dari dua jenis. Dengan kandungan unsur hara Nitrogen $15 \%$ dalam bentuk NH3, fosfor 15 $\%$ dalam bentuk P2O5, dan kalium $15 \%$ dalam bentuk K2O. Pemberian pupuk NPK terhadap tanah dapat berpengaruh baik pada kandungan hara tanah dan dapat berpengaruh baik bagi tanaman karena unsur hara makro yang terdapat dalam unsur N. P. dan K diperlukan bagi pertumbuhan dan perkembangan tanaman (Sutejo, 2002).

Berdasarkan latar belakang permasalahan diatas, penelitian ini dilakukan untuk mengetahui pengaruh pemberian abu sekam dan pupuk NPK pada tanaman tomat sehingga didapatkan peningkatan pertumbuhan dan hasil tanaman. Maka dari itu penulis membuat penelitian dengan judul "Pemberian Abu Sekam dan Pupuk NPK Terhadap Pertumbuhan Dan Hasil Tanaman Tomat".

\section{METODOLOGI}

\section{Waktu dan tempat}

Penelitian dilakukan pada bulan Februari 2018 sampai Mei 2018 di Desa Jingglong Lodoyo yang berdasarkan letak Geografis berada pada sebelah selatan katulistiwa antara 112,3' - 112,12' Bujur Timur dan 8,6' - 8,14' Lintang Selatan.

\section{Alat dan Bahan}


Farit Khoiruddin, Tri Kurniastuti \& Palupi Puspitorini, 2018. Pemberian Abu Sekam dan Pupuk NPK Terhadap Pertumbuhan dan Hasil Tanaman Tomat (Lycopersicum esculentum. Mill) Varietas Servo. Journal Viabel Pertanian. (2018), 12(2) 40 - 49

Peralatan yang digunakan adalah cangkul, ember, cetok, timbangan, gunting, meteran, gembor, sprayer, alat tulis, dan kamera. Bahan yang digunakan adalah benih tomat varietas intan, pupuk NPK, abu sekam, polibag ukuran 25 x $40 \mathrm{~cm}$, plastik, bambu.

\section{Metode Penelitian}

Penelitian ini dilakukan dengan menggunakan Rancangan Acak Kelompok (RAK) yang disusun secara factorial diulang tiga kali. Faktor kesatu adalah abu sekam (A) yang terdiri dari tiga level dan factor kedua pupuk NPK (P) yang terdiri dari tiga level.

Faktor pertama Dosis Abu Sekam yang terdiri dari 3 taraf yaitu :

A1 : Dosis abu sekam 50 gram/tanaman

A2 : Dosis abu sekam 60 gram/tanaman

A3 : Dosis abu sekam 70 gram/tanaman

Faktor kedua Dosis Pupuk NPK

P1 : Dosis pupuk NPK $250 \mathrm{~kg} / \mathrm{Ha}$ atau 2,50 gram/polybag

P2 : Dosis pupuk NPK $375 \mathrm{~kg} / \mathrm{Ha}$ atau 3,75 gram/polybag

P3 : Dosis pupuk NPK $500 \mathrm{~kg} / \mathrm{Ha}$ atau 5 gram/polybag

Dari kedua faktor tersebut diperoleh 9 kombinasi perlakuan setiap perlakuan diulang 3 kali sehingga didapat 27 satuan percobaan. Setiap satuan percobaan terdiri dari 3 tanaman dalam polybag. sehingga diperoleh jumlah seluruh tanaman yang dibutuhkan 81 tanaman.

\section{Analisis Data}

Data rata-rata hasil pengamatan dianalisis dengan menggunakan uji $\mathrm{F}$ pada taraf $5 \%$, kemudianbila data pengujian diperoleh hasil yang signifikan dilanjutkan denganuji DMRT pada taraf $5 \%$.

\section{Variabel Pengamatan}

Dalam penelitian ini yang perlu diamati adalah : tinggi tanaman, jumlah daun, umur tanaman berbunga, jumlah buah setiap tanaman dan bobot buah.

\section{HASIL PENELITIAN}

\section{Tinggi Tanaman}

Berdasarkan hasil analisis sidik ragam (ANOVA) pada taraf 5\% menunjukkan bahwa tidak terdapat interaksi yang nyata antara perlakuan pemberian abu sekam dan pupuk NPK terhadap tinggi tanaman tomat pada semua umur pengamatan. Perlakuan Pemberian Dosis Abu Sekam (A) memberikan pengaruh nyata terhadap tinggi tanaman tomat pada umur 14 HST, 21 HST dan 42 HST. Pada perlakuan Pemberian Dosis Pupuk NPK (P) memberikan pengaruh nyata terhadap tinggi tanaman tomat pada umur 28 HST dan 42 HST. (Lampiran 1). Uji lebih lanjut dengan menggunakan DMRT untuk mengetahui perlakuan terbaik dapat dilihat pada tabel 1 di bawah ini :

Tabel 1. Pemberian Abu Sekam (A) dan Pupuk NPK (P) Terhadap Tinggi Tanaman Tomat Pada Beberapa Umur (HST).

Perlakuan Tinggi Tanaman $(\mathrm{cm})$


Jurnal Viabel Pertanian Vol. 12 No.2 November 2018

p-ISSN: 1978-5259 e-ISSN: 2527-3345

Copyright@UNISBA Blitar, http://viabel.unisbablitar.ejournal.web.id

Farit Khoiruddin, Tri Kurniastuti \& Palupi Puspitorini, 2018. Pemberian Abu Sekam dan Pupuk NPK Terhadap Pertumbuhan dan Hasil Tanaman Tomat (Lycopersicum esculentum. Mill) Varietas Servo. Journal Viabel Pertanian. (2018), 12(2) 40 - 49

\begin{tabular}{lccccc}
\hline & $14 \mathrm{HST}$ & $21 \mathrm{HST}$ & $28 \mathrm{HST}$ & $35 \mathrm{HST}$ & $42 \mathrm{HST}$ \\
\hline \multicolumn{5}{c}{ Dosis Abu Sekam } \\
A1 $(50 \mathrm{~g})$ & $23.42 \mathrm{a}$ & $35.16 \mathrm{a}$ & $48.09 \mathrm{a}$ & $62.16 \mathrm{a}$ & $79.03 \mathrm{a}$ \\
A2 $(60 \mathrm{~g})$ & $24.09 \mathrm{a}$ & $36.92 \mathrm{ab}$ & $51.90 \mathrm{a}$ & $61.76 \mathrm{a}$ & $74.95 \mathrm{a}$ \\
A3 $(70 \mathrm{~g})$ & $26.04 \mathrm{~b}$ & $38.14 \mathrm{~b}$ & $50.91 \mathrm{a}$ & $65.60 \mathrm{a}$ & $87.89 \mathrm{~b}$ \\
\multicolumn{5}{c}{ Dosis Pupuk NPK } \\
P1 $(2,50 \mathrm{~g})$ & $24.74 \mathrm{a}$ & $36.52 \mathrm{a}$ & $46.52 \mathrm{a}$ & $58.45 \mathrm{a}$ & $76.27 \mathrm{a}$ \\
P2 (3,75 g) & $24.89 \mathrm{a}$ & $37.05 \mathrm{a}$ & $51.40 \mathrm{ab}$ & $64.30 \mathrm{a}$ & $81.55 \mathrm{ab}$ \\
P3 (5 g) & $23.92 \mathrm{a}$ & $36.65 \mathrm{a}$ & $52.18 \mathrm{~b}$ & $66.78 \mathrm{a}$ & $84.06 \mathrm{~b}$ \\
\hline
\end{tabular}

Keterangan : Angka-angka yang diikuti dengan huruf yang sama pada baris dan kolom yang sama tidak berbeda nyata pada uji Duncan $(\alpha=0,05)$.

Dari Tabel 1 di atas, pada tananaman umur 14 HST bahwa perlakuan pemberian dosis abu sekam $70 \mathrm{~g}$ (A3) menunjukkan hasil terbaik pada variabel tinggi tanaman tomat yaitu dengan hasil rata-rata $26,04 \mathrm{~cm}$. Sedangkan hasil rata-rata terendah terdapat pada perlakuan pemberian dosis abu sekam $50 \mathrm{~g}$ (A1) yaitu 23,42 $\mathrm{cm}$ juga tidak berbeda dengan perlakuan pemberian dosis abu sekam $60 \mathrm{~g}$ (A2). Pada pengamatan umur $21 \mathrm{HST}$ perlakuan pemberian dosis abu sekam $70 \mathrm{~g}$ (A3) menunjukan hasil rata-rata tertinggi yaitu $38,14 \mathrm{~cm}$ dan tidak berbeda dengan perlakuan pemberian dosis abu sekam $60 \mathrm{~g}$ (A2) dengan hasil rata-rata $36,92 \mathrm{~cm}$. Sedangkan hasil rata-rata terendah terdapat pada perlakuan pemberian dosis abu sekam $50 \mathrm{~g}$ (A1) yaitu $35,16 \mathrm{~cm}$. Pada pengamatan umur 42 HST bahwa perlakuan pemberian dosis abu sekam $70 \mathrm{~g}$ (A3) menunjukan rata-rata tinggi tanaman dengan hasil tertinggi yaitu $87,89 \mathrm{~cm}$ dan rata-rata paling rendah ditunjukan pada perlakuan pemberian abu sekam $60 \mathrm{~g}$ (A2). Dari hasil penelitian yang dilakukan oleh Kiswondo, S (2011) pada tanaman tomat dengan penggunaan abu sekam 50 gram / tanaman didapatkan bahwa abu sekam berpengaruh dalam meningkatkan pertumbuhan dan hasil tanaman tomat terhadap peningkatan pertumbuhan tinggi, diameter tanaman awal berbunga 14 HST maupun hasil jumlah buah 45 buah / tanaman, bobot buah tomat $1,87 \mathrm{~kg} /$ tanaman atau 69,4 ton per $\mathrm{Ha}$

Dari Tabel 1 juga menunjukan bahwa perlakuan pemberian pupuk NPK (P) pada tanaman tomat pada umur 28 HST dan 42 HST. Sebagaimana pendapat Lingga dan Marsono (2006), bahwa unsur hara nitrogen, posfor dan kalium yang berfungsi bagi tanaman untuk pembentukan sel-sel baru dan sejumlah protein tertentu serta membantu asimilasi yang dapat mempercepat pembuahan dan pemasakan buah. Pada pengamatan umur 28 HST perlakuan pemberian pupuk NPK 5 g (P3) dengan hasil rata-rata terbaik yaitu $52,18 \mathrm{~cm}$ dan tidak berbeda dengan perlakuan pemberian pupuk NPK 3,75 g (P2) yaitu $51,40 \mathrm{~cm}$. Pada perlakuan pemberian pupuk NPK 2,50 g (P1) menunjukan hasil paling rendah yaitu $46,52 \mathrm{~cm}$. Pada pengamatan umur $42 \mathrm{HST}$ perlakuan pemberian pupuk NPK $5 \mathrm{~g}$ (P3) terbaik yaitu $84,06 \mathrm{~cm}$ dan tidak berbeda dengan perlakuan pemberian pupuk NPK 3,75 g (P2) yaitu $81,55 \mathrm{~cm}$. Pada perlakuan pemberian pupuk NPK 2,50 g (P1) menunjukan hasil paling rendah yaitu $76,27 \mathrm{~cm}$.

\section{Jumlah Daun}

Berdasarkan hasil analisis sidik ragam (ANOVA) pada taraf 5\% menunjukkan bahwa tidak terdapat interaksi pada perlakuan pemberian dosis abu sekam (A) dan dosis 
Jurnal Viabel Pertanian Vol. 12 No.2 November 2018

p-ISSN: 1978-5259 e-ISSN: 2527-3345

Copyright@UNISBA Blitar, http://viabel.unisbablitar.ejournal.web.id

Farit Khoiruddin, Tri Kurniastuti \& Palupi Puspitorini, 2018. Pemberian Abu Sekam dan Pupuk NPK Terhadap Pertumbuhan dan Hasil Tanaman Tomat (Lycopersicum esculentum. Mill) Varietas Servo. Journal Viabel Pertanian. (2018), 12(2) 40 - 49

pupuk NPK (P) terhadap jumlah daun tanaman tomat pada semua umur pengamatan. Perlakuan pemberian dosis abu sekam berpengaruh nyata terhadap jumlah daun tanaman tomat pada umur $14 \mathrm{HSTdan} 21 \mathrm{HST}$. Pada pengamatan $21 \mathrm{HST}$ dan $28 \mathrm{HST}$ perlakuan pemberian pupuk NPK memberikan pengaruh nyata terhadap jumlah daun pada tanaman tomat. (Lampiran 2) Uji lebih lanjut dengan menggunakan DMRT untuk mengetahui perlakuan terbaik dapat dilihat pada tabel 2 di bawah ini :

Tabel 2. Pemberian Abu Sekam (A) dan Pupuk NPK (P) Terhadap Jumlah Daun Tanaman Tomat Pada Beberapa Umur HST.

\begin{tabular}{|c|c|c|c|c|c|}
\hline \multirow{2}{*}{ Perlakuan } & \multicolumn{4}{|c|}{ Jumlah Daun } & \multirow[b]{2}{*}{$42 \mathrm{HST}$} \\
\hline & $14 \mathrm{HST}$ & $21 \mathrm{HST}$ & $28 \mathrm{HST}$ & $35 \mathrm{HST}$ & \\
\hline \multicolumn{6}{|c|}{ Dosis Abu Sekam } \\
\hline A1 $(50 \mathrm{~g})$ & $7.55 \mathrm{a}$ & $10.46 \mathrm{a}$ & $14.18 \mathrm{a}$ & $16.74 \mathrm{a}$ & $19.48 \mathrm{a}$ \\
\hline A2 $(60 \mathrm{~g})$ & $7.55 \mathrm{a}$ & $11.22 \mathrm{ab}$ & $14.74 \mathrm{a}$ & $17.48 \mathrm{a}$ & $20.33 \mathrm{a}$ \\
\hline A3 (70 g) & $8.29 \mathrm{~b}$ & $11.48 \mathrm{~b}$ & $14.44 \mathrm{a}$ & $17.29 \mathrm{a}$ & $20.29 \mathrm{a}$ \\
\hline \multicolumn{6}{|c|}{ Dosis Pupuk NPK } \\
\hline P1 $(2,50 \mathrm{~g})$ & $7.70 \mathrm{a}$ & $10.88 \mathrm{a}$ & $13.96 \mathrm{a}$ & $16.88 \mathrm{a}$ & $19.62 \mathrm{a}$ \\
\hline $\mathrm{P} 2(3,75 \mathrm{~g})$ & $8.00 \mathrm{a}$ & $11.55 \mathrm{~b}$ & $14.96 \mathrm{~b}$ & $17.33 \mathrm{a}$ & $20.29 \mathrm{a}$ \\
\hline P3 (5 g) & $7.70 \mathrm{a}$ & $11.22 \mathrm{ab}$ & $14.44 \mathrm{ab}$ & $17.29 \mathrm{a}$ & $20.18 \mathrm{a}$ \\
\hline
\end{tabular}

Keterangan : Angka-angka yang diikuti dengan huruf yang sama pada baris dan kolom yang sama tidak berbeda nyata pada uji Duncan $(\alpha=0,05)$.

Dari Tabel 2 di atas menujukan pada umur 14 HST terdapat perbedaan nyata. Bahwa pemberian abu sekam pada tanaman tomat memberikan pengaruh nyata terhadap laju pertumbuhan tinggi tanaman Martanto (2001). pada perlakuan pemberian dosis abu sekam 70 g (A3) dengan jumlah daun terbaik yaitu 8, 29 sedangkan rata-rata pada perlakuan pemberian dosis abu sekam $50 \mathrm{~g}$ (A1) tidak berbeda dengan perlakuan pemberian dosis abu sekam 60 (A2). Dari pengamatan umur 21 HST yang menunjukkan jumlah daun terbaik yaitu 11,48 pada perlakuan pemberian dosis abu sekam $70 \mathrm{~g}$ (A3) dan tidak berbeda dengan perlakuan pemberian dosis abu sekam $60 \mathrm{~g}$ (A2) Sedangkan yang menunjukkan jumlah daun terendah yaitu 10,46 pada perlakuan pemberian dosis abu sekam $50 \mathrm{~g}$ (A1).

Dari Tabel 2 juga juga menunjukan bahwa pada pengamatan umur 21 HST menunjukan perbedaan yang nyata terhadap jumlah daun tanaman tomat. Pada perlakuan pemberian dosis pupuk NPK 3,75 g (P2) menunjukan jumlah daun terbaik yaitu 11,55 dan tidak berbeda dengan perlakuan pemberian dosis pupuk NPK $5 \mathrm{~g}$ (P3) yaitu 11,22. Pada perlakuan pemberian dosis pupuk NPK 2,50 g (P1) menunjukan jumlah daun paling rendah yaitu 10,46 . Pada pengamatan umur 28 HST terjadi perbadaan yang nyata terhadap jumlah daun tanaman tomat, pada perlakuan pemberian dosis pupuk NPK 2,50 g (P1) menunjukan hasil terendah yaitu 13,96 dan pada perlakuan pemberian dosis pupuk NPK 3,75 g (P2) menunjukan hasil terbaik yaitu 14,96 dan tidak berbeda dengan perlakuan pemberian dosis pupuk NPK 5 g (P3) yaitu 14,44. Pada pengamatan umur 35 HST dan umur 42 HST tidak menunjukan perbedaan yang nyata terhadap jumlah daun. Pemberian pupuk NPK pada tanaman tomat berfungsi dalam pertumbuhan vegetatif tanaman yang meliputi daun, cabang, dan akar sebagai komponen molekul enzim dan molekul klorofil yang berperan 
Farit Khoiruddin, Tri Kurniastuti \& Palupi Puspitorini, 2018. Pemberian Abu Sekam dan Pupuk NPK Terhadap Pertumbuhan dan Hasil Tanaman Tomat (Lycopersicum esculentum. Mill) Varietas Servo. Journal Viabel Pertanian. (2018), 12(2) 40 - 49

dalam proses transfer energi di dalam sel, dan dalam proses perombakan fotosintat menjadi molekul sederhana yang disusun kembali menjadi molekul bahan lain yang dikehendaki pada proses metabolisme sel tanaman (Spiertz \& Ellen 1978).

\section{Waktu Tanaman Berbunga}

Berdasarkan hasil analisis sidik ragam (ANOVA) pada taraf 5\% menunjukkan bahwa tidak terdapat interaksi yang nyata antara perlakuan pemberian dosis abu sekam dan pupuk NPK terhadap waktu tanaman tomat berbunga. Masing-masing perlakuan pemberian abu sekam (A) dan pemberian pupuk NPK (P) tidak berpengaruh nyata terhadap waktu tanaman tomat berbunga. (lampiran 3) Untuk mengetahui perlakuan terbaik dapat dilihat pada tabel di awah ini :

Tabel 3. Pemberian Abu Sekam (A) dan Pupuk NPK (P) Terhadap Waktu Tanaman Tomat Berbunga.

\begin{tabular}{lc}
\hline Perlakuan & Umur Tanaman Berbunga (HST) \\
\hline & Dosis Abu Sekam \\
A1 $(50 \mathrm{~g})$ & $28.48 \mathrm{a}$ \\
A2 $(60 \mathrm{~g})$ & $28.55 \mathrm{a}$ \\
A3 $(70 \mathrm{~g})$ & $28.59 \mathrm{a}$ \\
& Dosis Pupuk NPK \\
P1 $(2.50 \mathrm{~g})$ & $28.66 \mathrm{a}$ \\
P2 $(3.75 \mathrm{~g})$ & $28.44 \mathrm{a}$ \\
P3 $(5 \mathrm{~g})$ & $28.51 \mathrm{a}$ \\
\hline
\end{tabular}

Keterangan : Angka-angka yang diikuti dengan huruf yang sama pada baris dan kolom yang sama tidak berbeda nyata pada uji Duncan $(\alpha=0,05)$.

Dari Tabel 3 di atas menunjukan bahwa tidak terdapat perbedaan yang nyata pada masing-masing perlakuan pemberian abu sekam (A) dan perlakuan pemberian pupuk NPK (P) terhadap waktu tanaman tomat berbunga.

\section{Jumlah Buah}

Berdasarkan hasil analisis sidik ragam (ANOVA) pada taraf 5\% menunjukkan bahwa tidak terdapat interaksi antara perlakuan pemberian dosis abu sekam dan pupuk NPK terhadap jumlah buah per tanaman dan jumlah buah total. Perlakuan pemberian abu sekam (A) dan perlakuan pemberian pupuk NPK (P) tidak memberikan pengaruh yang nyata terhadap jumlah buah per tanaman dan jumlah buah total tanaman tomat pada semua 
Jurnal Viabel Pertanian Vol. 12 No.2 November 2018

p-ISSN: 1978-5259 e-ISSN: 2527-3345

Copyright@UNISBA Blitar, http://viabel.unisbablitar.ejournal.web.id

Farit Khoiruddin, Tri Kurniastuti \& Palupi Puspitorini, 2018. Pemberian Abu Sekam dan Pupuk NPK Terhadap Pertumbuhan dan Hasil Tanaman Tomat (Lycopersicum esculentum. Mill) Varietas Servo. Journal Viabel Pertanian. (2018), 12(2) 40 - 49

waktu panen. (lampiran 4) Untuk mengetahui perlakuan terbaik dapat dilihat pada tabel di awah ini :

Tabel 4. Pemberian Abu Sekam (A) dan Pupuk NPK (P) Terhadap Jumlah Buah Tanaman Tomat pada saat Panen.

\begin{tabular}{lccccc}
\hline \multirow{2}{*}{ Perlakuan } & \multicolumn{5}{c}{ Jumlah Buah } \\
& Panen 1 & Panen 2 & Panen 3 & Panen 4 & Total \\
\hline & & \multicolumn{7}{c}{ Dosis Abu Sekam } \\
A1 $(50 \mathrm{~g})$ & $1.66 \mathrm{a}$ & $2.74 \mathrm{a}$ & $5.18 \mathrm{a}$ & $4.88 \mathrm{a}$ & $14.48 \mathrm{a}$ \\
A2 $(60 \mathrm{~g})$ & $1.59 \mathrm{a}$ & $2.51 \mathrm{a}$ & $5.44 \mathrm{a}$ & $5.74 \mathrm{a}$ & $15.29 \mathrm{a}$ \\
A3 $(70 \mathrm{~g})$ & $1.77 \mathrm{a}$ & $2.55 \mathrm{a}$ & $6.37 \mathrm{a}$ & $5.48 \mathrm{a}$ & $16.18 \mathrm{a}$ \\
& & Dosis Pupuk NPK & & \\
P1 $(2,50 \mathrm{~g})$ & $1.48 \mathrm{a}$ & $2.48 \mathrm{a}$ & $5.55 \mathrm{a}$ & $5.33 \mathrm{a}$ & $14.85 \mathrm{a}$ \\
P2 $(3,75 \mathrm{~g})$ & $1.81 \mathrm{a}$ & $2.81 \mathrm{a}$ & $5.92 \mathrm{a}$ & $5.59 \mathrm{a}$ & $16.14 \mathrm{a}$ \\
P3 $(5 \mathrm{~g})$ & $1.74 \mathrm{a}$ & $2.51 \mathrm{a}$ & $5.51 \mathrm{a}$ & $5.18 \mathrm{a}$ & $14.96 \mathrm{a}$ \\
\hline
\end{tabular}

Keterangan : Angka-angka yang diikuti dengan huruf yang sama pada baris dan kolom yang sama tidak berbeda nyata pada uji Duncan $(\alpha=0,05)$.

Dari Tabel 4 di atas bahwa masing-masing perlakuan pemberian dosis abu sekam (A) tidak memberikan pengaruh yang nyata pada waktu panen 1, panen 2 , panen 3 , dan panen 4 terhadap jumlah buah tanaman tomat.

Dari Tabel 4 diatas bahwa semua perlakuan pemberian dosis pupuk NPK (P) tidak memberikan perbedaan yang nyata terhadap jumlah buah dalam $4 x$ panen.

\section{Bobot Buah pertanaman}

Berdasarkan hasil analisis sidik ragam (ANOVA) pada taraf 5\% menunjukkan bahwa tidak terdapat interaksi antara perlakuan pemberian dosis abu sekam dan pupuk NPK terhadap bobot buah per tanaman. Perlakuan pemberian abu sekam (A) memberikan pengaruh yang nyata terhadap bobot buah tanaman tomat pada waktu panen 1 , panen 2 , dan panen 3. Pada perlakuan pemberian dosis pupuk NPK (P) memberikan pengaruh yang nyata terhadap bobot buah tanaman tomat pada waktu panen pertama. (lampiran 5) Uji lebih lanjut dengan menggunakan DMRT untuk mengetahui perlakuan terbaik dapat dilihat pada tabel 5 di bawah ini :

Tabel 5. Pemberian Abu Sekam (A) dan Pupuk NPK (P) Terhadap Bobot Buah Tanaman Tomat.

\begin{tabular}{lccrrc}
\hline \multirow{2}{*}{ Perlakuan } & \multicolumn{5}{c}{ Bobot Buah Pertanaman $(\mathbf{g})$} \\
& Panen 1 & Panen 2 & Panen 3 & Panen 4 & Total \\
\hline A1 $(50 \mathrm{~g})$ & $52.66 \mathrm{~b}$ & $89.55 \mathrm{~b}$ & $163.48 \mathrm{a}$ & $149.04 \mathrm{a}$ & $454.74 \mathrm{a}$ \\
$\mathrm{A} 2(60 \mathrm{~g})$ & $38.96 \mathrm{a}$ & $81.46 \mathrm{~b}$ & $177.33 \mathrm{a}$ & $173.46 \mathrm{a}$ & $478.04 \mathrm{a}$ \\
$\mathrm{A} 3(70 \mathrm{~g})$ & $50.70 \mathrm{ab}$ & $65.72 \mathrm{a}$ & $226.37 \mathrm{~b}$ & $164.85 \mathrm{a}$ & $507.65 \mathrm{a}$ \\
& \multicolumn{7}{c}{ Dosis Pupuk NPK } \\
P1 $(2,50 \mathrm{~g})$ & $36.48 \mathrm{a}$ & $84.70 \mathrm{a}$ & $179.70 \mathrm{a}$ & $148.65 \mathrm{a}$ & $449.54 \mathrm{a}$ \\
P2 $(3,75 \mathrm{~g})$ & $49.14 \mathrm{~b}$ & $83.88 \mathrm{a}$ & $211.11 \mathrm{a}$ & $175.52 \mathrm{a}$ & $526.48 \mathrm{a}$
\end{tabular}


Jurnal Viabel Pertanian Vol. 12 No.2 November 2018

p-ISSN: 1978-5259 e-ISSN: 2527-3345

Copyright@UNISBA Blitar, http://viabel.unisbablitar.ejournal.web.id

Farit Khoiruddin, Tri Kurniastuti \& Palupi Puspitorini, 2018. Pemberian Abu Sekam dan

Pupuk NPK Terhadap Pertumbuhan dan Hasil Tanaman Tomat (Lycopersicum esculentum. Mill) Varietas Servo. Journal Viabel Pertanian. (2018), 12(2) 40 - 49

\begin{tabular}{cccccc}
\hline P3 $(5 \mathrm{~g})$ & $56.70 \mathrm{~b}$ & $64.14 \mathrm{a}$ & $176.37 \mathrm{a}$ & $163.19 \mathrm{a}$ & $464.41 \mathrm{a}$ \\
\hline Keterangan : Angka-angka yang diikuti dengan huruf yang sama pada baris dan kolom yang sama \\
tidak & berbeda & nyata & pada uji $\quad$ Duncan $(\alpha \quad 0 \quad 05)$.
\end{tabular}

Dari Tabel 5 diatas menunjukan bahwa terdapat perbedaan yang nyata pada perlakuan pemberian dosis abu sekam (A) terhadap bobot buah tanaman tomat pada waktu panen 1, panen 2, dan panen 3. Pada pengamatan bobot buah panen 1 perlakuan pemberian dosis abu sekam $50 \mathrm{~g}$ (A1) menunjukan rata-rata bobot buah terbaik yaitu 52,66 g dan tidak berbeda dengan perlakuan pemberian dosis abu sekam $70 \mathrm{~g}$ (A3) yaitu 50,70 g. sedangkan hasil paling rendah ditunjukan pada perlakuan pemberian dosis abu sekam $60 \mathrm{~g}$ (A2). Pada pengamatan bobot buah panen 2 rata-rata paling tinggi ditunjukan pada perlakuan pemberian dosis abu sekam $50 \mathrm{~g}$ (A1) yaitu 89,55 g dan tidak berbeda dengan perlakuan pemberian dosis abu sekam $60 \mathrm{~g}$ (A2) yaitu 81,46 g. Sedangkan hasil paling rendah ditunjukan pada perlakuan pemberian dosis abu sekam $60 \mathrm{~g} \mathrm{(A2)} \mathrm{yaitu} \mathrm{65,72} \mathrm{g.}$

Dari Tabel 5. juga menunjukan bahwa perlakuan pemberian dosis pupuk NPK (P) berpengaruh nyata terhadap bobot buah tanaman tomat pada panen 1 . Pada perlakuan pemberian dosis pupuk NPK $5 \mathrm{~g}$ (P3) menunjukan bobot buah paling tinggi yaitu 56,70 g dan rata-rata paling rendah ditunjukan pada perlakuan pemberian dosis pupuk NPK 2,50 $\mathrm{g}$ (P1) yaitu 36,48 g. Pada pengamatan bobot buah panen 2, panen 3, dan panen 4 tidak menunjukan perbedaan yang nyata pada masing-masing perakuan pemberian dosis pupuk NPK (P).

Namun pada bobot total tidak terdapat perbedaan yang nyata. sehingga hasil panen tidak signifikan. Hal ini diduga karena pada tanaman tersebut terjadi kekurangan unsur hara yang diperlukan oleh tanaman tomat pada saat fase reproduksi. Ketersediaan pupuk yang sesuai dengan kebutuhan tanaman dapat memberikan hasil yang terbaik. Efisiensi serapan merupakan keseimbangan antara hara yang dapat diserap tanaman dengan hara yang diberikan. Seperti yang dikemukakan Dwidjoseputro (1988) bahwa tanaman akan tumbuh dengan subur apabila elemen (unsure hara) yang dibutuhkan media cukup dan unsure hara tersebut dalam bentuk yang dapat diserap oleh tanaman. Tanaman tomat membutuhkan unsure nitrogen, fosfor, dan kalium dalam jumlah yang relatif banyak, oleh karena itu unsure N,P,K harus tersedia bagi tanaman sesuai kebutuhan tanaman. Bila ketiga unsur hara ini tidak tersedia atau tidak seimbang bagi tanaman, maka perkembangan tanaman akan terhambat (Sarwono 1995).

\section{KESIMPULAN}

Berdasarkan hasil penelitian mengenai Pemberian Abu Sekam dan Pupuk NPK Terhadap Pertumbuhan dan Hasil Tanaman Tomat dapat disimpulkan sebagai berikut :

Pemberian dosis abu sekam memberikan perbedaan yang nyata pada tinggi tanaman umur 14 HST, 21 HST, 28 HST dan 42 HST, jumlah daun dan bobot buah. Perlakuan pemberian dosis abu sekam terbaik yaitu pada pemberian dosis abu sekam $70 \mathrm{~g}$ (A3). 
Farit Khoiruddin, Tri Kurniastuti \& Palupi Puspitorini, 2018. Pemberian Abu Sekam dan Pupuk NPK Terhadap Pertumbuhan dan Hasil Tanaman Tomat (Lycopersicum esculentum. Mill) Varietas Servo. Journal Viabel Pertanian. (2018), 12(2) 40 - 49

Pemberian dosis pupuk NPK memberikan perbedaan yang nyata pada tinggi tanaman umur, jumlah daun dan bobot buah. Perlakuan pemberian dosis pupuk NPK terbaik yaitu pada pemberian dosis pupuk NPK 3,75 g (P2).

Tidak terdapat pengaruh interaksi antara pemberian dosis abu sekam dan pemberian dosis pupuk NPK terhadap pertumbuhan dan hasil tanaman tomat di semua umur pengamatan.

\section{SARAN}

Dari penelitian ini penulis menyarankan pemberian abu sekam pada media tanam dapat meningkatkan pertumbuhan dan hasil pada tanaman tomat. Hal ini dikarenakan, pemberian abu sekam dapat meningkatkan ruang pori total dan mempercepat drainase air tanah. Seain itu abu sekam berfungsi untuk menggemburkan tanah, sehingga mempermudah akar tanamn menyerap unsure hara. Untuk memperoleh pertumbuhan dan hasil tanaman tomat yang maksimal perlu dilakukan penelitian lebih lanjut tentah pemberian abu sekam dan pupuk NPK terhadap pertumbuhan dan hasil tanaman tomat.

\section{DAFTAR PUSTAKA}

Agromedia, Redaksi.2007. Panduan Lengkap Budidaya Tomat. Agromedia, Jakarta.

Agustina, L. 2004. Dasar Nutrisi Tanaman. Rineka Cipta. Jakarta.

A, Kasno. (2009). Jenis dan Sifat Pupuk Anorganik. Balai Penelitian Tanah.Bank Pengetahuan Padi Indonesia.

Departemen pertanian. 2004. Hasil Tomat Menurut Propinsi. http://www.deptan.go.id/infoeksekutif/horti/hasil_tomat_perpropinsi.htm. diakses Juni 2005.

Harjadi, S. S., dan H. Sunarjono. 1989. Budidaya Tomat. Hal: 244-269. Dalam Harjadi, S.S. (ed), Dasar-dasar Hortikultura. Fakultas Pertanian, Jurusan Budidaya Pertanian, IPB. Bogor.

Hardjowigeno, S. 2003. Ilmu Tanah. Akamedika Pressindo. Jakarta.

Ismail, M. S. dan Waliuddin, A. M. 1996. Effect of Rice Husk Ash on High Strength Concrete. Construction and Building Materials. 10 (1):521 - 526

Kurniati, N. 2013. Kriteria Bibit Tanaman yang Baik. http://www.tanijogonegoro.com/2013/08/ bibit-tanaman.html. (Diakses pada tanggal : 24 Maret 2015).

Martanto. 2001. Pengaruh Abu Sekam Terhadap Pertumbuhan Tanaman Dan Intensitas Penyakit Layu Fusarium Pada Tomat. Jurnal Irian Jaya Agro 8: 37-40. 
Jurnal Viabel Pertanian Vol. 12 No.2 November 2018

p-ISSN: 1978-5259 e-ISSN: 2527-3345

Copyright@UNISBA Blitar, http://viabel.unisbablitar.ejournal.web.id

Farit Khoiruddin, Tri Kurniastuti \& Palupi Puspitorini, 2018. Pemberian Abu Sekam dan

Pupuk NPK Terhadap Pertumbuhan dan Hasil Tanaman Tomat (Lycopersicum esculentum.

Mill) Varietas Servo. Journal Viabel Pertanian. (2018), 12(2) 40 - 49

Nurtika, N. 1984. Pengaruh Pupuk Kandang dan NPK (15-15-15) terhadap Pertumbuhan dan Produksi Tomat. Bul.Penel.Hort. 1(4):1-7.

Pitojo,S. 2005. Benih Tomat. Kanisius. Yogyakarta

Prasetyoko, D., (2001), "Pengoptimuman Sintesis Zeolit dari pada Silika abu sekam padi Pencirian dan Tindak Balas Pemangkinan Friedel Crafts", MSc thesis, Universiti Teknologi Malaysia, Malaysia.

Rismunandar. 2001. Tanaman Tomat. Sinar Baru Algesindo: Jakarta.

Rosliani, R., N. Sumarni, dan N. Nurtika. 2001. Penentuan Pupuk Makro dan Macam Naungan untuk Tanaman Cabai di Musim Hujan. J. Hort. 11(2):102-109.

Sarief, S. 1986. Kesuburan dan Pemupukan Tanah Pertanian. Pustaka Buana. Bandung.

Sarwono, H. 1995. Ilmu Tanah. Akademik Pressindo, Jakarta. 87 Hlm.

Sumiati, E. 2005. Pertumbuhan dan Hasil Kentang dengan Aplikasi NPK 15-15-15 dan Pupuk Pelengkap Cair di Dataran Tinggi. J. Hort. 15(4):270-278.

Surawinata, E.T. 2003. Pengaruh Berbagai Kombinasi Pupuk Organik Asal TPA Bantargebang dan Pupuk Anorganik terhadap Pertumbuhan dan Hasil Tanaman Tomat Varietas Arthaloka. Jurnal Agrikultura 14: 139-144.

Suriadikarta, Didi Ardi., Simanungkalit, R.D.M. (2006). Pupuk Organik dan Pupuk Hayati. Jawa Barat: Balai Besar Penelitian dan Pengembangan Sumberdaya Lahan Pertanian. Hal 2. ISBN 978-979-9474-57-5.

Sutedjo, M, M., Kartasapoetra dan A, G.,Sastroatmodjo, S. 1996. Mikro Biologi TanahRineka Cipta. Jakarta.

Suwahyono, Untung. 2011. Petunjuk Praktis Penggunaan Pupuk Organik Secara Efektif Dan Efisien. Jakarta: Penebar Swadaya.

Tugiyono. 2005. Tanaman Tomat. Agromedia Pustaka. Jakarta: 250 halaman

Wiryanta, B.T.W. 2002. Kiat Mengatasi Permasalahan Praktis Bertanam Tomat. Jakarta: Agro Media Pustaka.

Wiryanta,W.T.B, 2004. Bertanam Tomat. Agromedia Pustaka, Jakarta. 